\title{
Costs of biosecurity measures in Brazilian laying hens farms in response to policies against Avian Influenza, Newcastle Disease and Salmonellosis
}

\author{
Custos das medidas de biosseguridade na produção brasileira de galinhas poedeiras \\ em resposta às políticas sanitárias contra a gripe aviária, doença de Newcastle e \\ Salmonelose
}

\author{
LAGATTA, Luciano ${ }^{1}$; GAMEIRO, Augusto Hauber ${ }^{2 *}$
}

\begin{abstract}
${ }^{1}$ Secretaria da Agricultura do Estado de São Paulo, Coordenadoria de Defesa Agropecuária, Campinas, São Paulo, Brasil

${ }^{2}$ Universidade de São Paulo, Faculdade de Medicina Veterinária e Zootecnia, Departamento de Nutrição e Produção Animal, Pirassununga, São Paulo, Brasil.

*Endereço para correspondência: gameiro@usp.br
\end{abstract}

\section{SUMMARY}

The objective of this study was to estimate costs for egg production and for implementation of biosecurity measures described by Normative Instructions No. 56/2007, No. 59/2009, No. $36 / 2012$ and No. $10 / 2013$ on production costs in these establishments. To attend the "National Avian Health Program" and the "National Plan for the Prevention of Avian Influenza and Control and Prevention of Newcastle Disease", the Brazilian Ministry of Agriculture published a series of legal acts to establish the "Procedures for Register, Inspection and Control of Breeding and Commercial Avian Establishments" intensifying the measures for prevention of high economic impact illnesses in avian flocks of the country. The adaptations comprise items of structure and biosecurity procedures that aim to increase the level of isolation of the birds to maintain them with the best health status as possible. These adaptations can result in more expenses and dedication from the producers. Thus, production costs were obtained through personal interviews with 10 voluntary commercial farmers of laying hens in Limeira region, Sao Paulo State, Brazil, between June and July, 2013. The result of this study suggests that the implementation of biosecurity measures has relatively low costs when compared to the possible risks of diseases outbreaks and the consequent economic losses that justify the adoption of these practices.

Keywords: avian health programs, biosecurity, production cost

\section{RESUMO}

O objetivo com este trabalho foi estimar os custos para produção de ovos, bem como os impactos da implementação das normas de biosseguridade descritas pelas normativas de número 56/2007, 59/2009, 36/2012, 10/2013. Visando o atendimento ao "Programa Nacional de Sanidade Avícola" e ao "Plano Nacional de Prevenção da Influenza Aviária e de Controle e Prevenção da Doença de Newcastle", o Ministério da Agricultura publicou uma série de atos legais para estabelecer os "Procedimentos para Registro, Fiscalização e Controle de Estabelecimentos Avícolas de Reprodução e Comerciais", intensificando as medidas para prevenção da ocorrência de enfermidades de grande impacto econômico no plantel avícola do país. As adequações englobam itens de estrutura e procedimentos de biosseguridade que visam aumentar o nível de isolamento das aves, para mantê-las com o melhor status sanitário possível. Essas exigências podem resultar em mais despesas e dedicação por parte dos produtores. Desta forma, custos de produção foram obtidos por meio de entrevistas pessoais com 10 produtores de fazendas comerciais de avicultura de postura na região de Limeira, Estado de São Paulo, Brasil, entre junho e julho de 2013. O resultado deste estudo sugere que a implantação da biosseguridade tem custo relativamente baixo frente aos possíveis riscos de enfermidades e dos prejuízos econômicos que essas enfermidades podem causar, o que justifica a adoção destas práticas.

Palavras-chave: programas de sanidade avícola, biossegurança, custo de produção 


\section{INTRODUCTION}

The World Organization of Animal Health listed 115 diseases of compulsory notification, where 12 of them affect poultry, with special distinction to Avian Influenza, Newcastle Disease, Mycoplasmosis, Salmonellosis and Infectious Laryngotracheitis (OIE, 2014).

The Ministry of Agriculture, Livestock and Food Supply - MAPA, published the Ministerial Order No. 193 from September 19, 1994 which consolidated and structured the National Avian Health Program (PNSA) (BRASIL, 1994). In December 04, 2007, MAPA published the Normative Instruction (NI) No. 56, which established the "Procedures for Register, Inspection and Control of Breeding and Commercial Avian Establishments", revoking the NI No. 4, which had approved the rules for register and supervision of avian establishments at December 30, 1998 (BRASIL, 2007).

The NI No. 56 introduced some procedures such as wire mesh, installation in the whole shed, isolation of shed through fences to avoid free passage of animals and people, vehicle disinfection, registry of the flock activities and good manufacturing practices (BRASIL, 2007). However, to attend a request from the sector, MAPA published NI No. 59 of December 02, 2009, which did not revoke NI No. 56, but altered the metric patterns and the date fixed by NI No. 56. This NI came into force in December 06, 2012 (BRASIL, 2009).

To attend another request of the sector, in December 06, 2012, MAPA published Normative Instruction No. 36, altering parts of NI No. 56. This excluded the registration obligation of avian establishments that have less than 1,000 birds and excluded the obligation of wire mesh installation due to its technical impossibility of installation in commercial classic or modified type California laying hen sheds (BRASIL, 2012).

In April 11, 2013, the NI No. 10 defined the Program of Risk Management, based in sample collection for laboratory analysis and vaccination for more susceptible avian establishments to the introduction and dissemination of pathogenic agents in national avian flocks and avian establishments that exert activities of higher sanitary rigor (BRASIL, 2013).

The situation brings concern to the sector in relation to costs necessary to attend the requirements, especially, for small producers (SEAGRI, 2010). The objective with this study was to estimate costs for eggs production and for implementation of biosecurity measures described by Normative Instructions No. 56/2007, No. 59/2009, No. 36/2012 and No. 10/2013.

\section{MATERIAL AND METHODS}

The selection of commercial laying hen's farms which participate in this research was conducted along with the Agriculture and Livestock Defense Office in Limeira, São Paulo, Brazil. This office is part of the public administration of São Paulo state government linked to the Secretary of Agriculture and Supply, responsible for the accomplishment of animal health defense programs in São Paulo state (SÃO PAULO, 1998).

According to a survey performed by the Agriculture and Livestock Defense Office of Limeira, the sectional is composed by 28 commercial laying hens farms in registry process, representing $5.3 \%$ of the laying hen 
farms of São Paulo state, Brazil and corresponding to $1.49 \%$ of the state stock of laying hens.

The research instrument was the method face-to-face interview. According to Veiga \& Gondim (2001), as they are discursive, face-to-face interviews have as advantage the possibility of the interviewee to show his argumentation line in a way to allow the interviewer to associate them, offering thus opportunities to identify the opinions, attitudes and values of the interview. The research had an exploratory character and for the estimation costs of production and biosecurity measures, data were obtained in ten voluntary establishments between June and July, 2013.

The methodology adopted was the lamb costs calculation proposed by Raineri et al. (2015) in which the basis for the costs allocation scheme was the Economic Theory and different methods used in agriculture. Thus, in economic terms, cost components were grouped into the categories of variable, fixed, total and operational cost. A simulator was developed in Excel $^{\circledR}$ software MICROSOFT (2007), adapted to laying activity, in a way to facilitate the practical use of the model, also following a logic that the producers could understand, adopt and at the same time attend to the economic and animal science principles to estimate production costs.

Thus, for the estimation of costs for biosecurity measures implementation, four sceneries were simulated in a way that scenery I (basic scenery) presents the estimation of production costs without the compliance of requirements in normative instruction (NI) No. 56, but considering all production factors. Table 1 presents the description of the proposed scenarios.

Table 1. Scenarios considered and their description

\begin{tabular}{ll}
\hline Scenery & \multicolumn{1}{c}{ Description } \\
\hline \multirow{2}{*}{ I (basic scenery) } & Considers the production costs without the compliance of requirements in NI \\
No. 56 & Includes the requirements described by NI No. 56 and No. 59 \\
& Includes the requirements described by NI No. 36 and No. 10 (which means, \\
& without the obligation of wire mesh installation according to the "Program of \\
III & Risk Management") \\
& $\begin{array}{l}\text { Presents the estimation of costs considering all NI including the wire mesh } \\
\text { installation in poultry sheds and exams for salmonella sp. infection. }\end{array}$ \\
IV &
\end{tabular}

The biosecurity measures required by normative instructions in analysis for costs composition were wire mesh installation; isolation fence; point for vehicle disinfection; compost heap; cleaning procedures; shed and other installations disinfection; physicalchemical and microbiological water analysis; rodent and pest control; exams for salmonella isolation and identification, as well as, technical responsibility by a veterinary physician.

\section{RESULTS AND DISCUSSION}

The prevention and control of pathogens are a constant challenge in avian sector. The environment in the production system can be a potential 
source of infections and the severity and outbreaks of the diseases are directly related to the level of contamination of the environment (DUMAS et al., 2011). According to Sesti (2005), the adoption of an effective biosecurity program is the best alternative to maintain commercial flocks free or controlled from the presence of diseases of economic impact in productivity or dangerous to public health.

The word biosecurity means the establishment of a security level by the reduction of acute and/or chronic outbreak in a determined population. This general concept is applicable to populations of any animal species and in the present case, the modern industrial avian flocks (SESTI, 2005).

Table 2 presents a comparison of the average costs between the different sceneries. The production cost for scenery I (basis) without requirements described by Normative Instructions was in average US\$ 25.05 (R\$ 57.15 Brazilian current money) per egg box with 30 dozen. The costs with health and biosecurity measures with adjustments to Normative Instructions, as simulated by sceneries II, III and IV, corresponded, respectively to $1.89 \%, 1.61 \%$ and $2.09 \%$ of total cost of production. The increments in production costs between the sceneries II, III and IV, represented between 0.28 percentage point (p.p.) to 0.5 p.p. The costs were relatively low compared to damages that these risks represent to avian sector. As, according to Mexican experience, the outbreak of Avian Influenza had huge damages to the production sector of birds, fertile eggs and eggs.

Table 2. Comparative average costs between the sceneries costs and the requirements indicated by Normative Instructions No. 56, No. 59, No. 36 and No. 10

\begin{tabular}{lcccc}
\hline Item & Scenery I & Scenery II & Scenery III & Scenery IV \\
\hline Mean cost of production / box & US\$ 25.05 & US\$ 25.54 & US\$ 25.47 & US\$ 25.59 \\
Animal health and biosecurity & $0 \%$ (R7.15) & (R\$ 58.25) & (R\$ 58.09) & (R \$ 58.37) \\
\hline Isolation fence & - & $1.89 \%$ & $1.61 \%$ & $2.09 \%$ \\
Wire mesh installation & - & $16.45 \%$ & $16.58 \%$ & $14.26 \%$ \\
Disinfection equipment & - & $17.79 \%$ & - & $15.17 \%$ \\
Compost heap & - & $4.05 \%$ & $4.05 \%$ & $3.42 \%$ \\
Technical responsibility & - & $2.92 \%$ & $2.93 \%$ & $2.48 \%$ \\
Water analysis & - & $46.87 \%$ & $47.39 \%$ & $40.05 \%$ \\
Pest and rodents control & - & $0.68 \%$ & $0.69 \%$ & $0.58 \%$ \\
Cleaning and disinfection & - & $2.26 \%$ & $2.29 \%$ & $1.93 \%$ \\
Salmonellosis diagnosis & - & $8.87 \%$ & $8.96 \%$ & $7.57 \%$ \\
\hline Scery I (basis & - & $17.13 \%$ & $14.54 \%$ \\
\hline
\end{tabular}

Scenery I: (basis scenery) presents the estimation of production costs without the attendance of requirements of NI No. 56, but considering all factors of production. Scenery II: includes the requirements suggested by No. 56 and No. 59. Scenery III: presents the estimation of costs considering the requirements of NI No. 36 and No. 10, which means, without the obligation of wire mesh installation and in accordance to the "Program of Risk Management". Scenery IV: presents the estimation of cost considering all NI, which means, including the wire mesh installation and salmonella diagnosis exams.

US\$ $1.00=$ R\$ 2.2809 (July 31, 2013)

Source: Research data. 
In the Jalisco region, located in centralwest of Mexico, during June 2012, high mortality was reported in laying hen farms. The disease was first diagnosed as Avian Cholera, after as Newcastle Disease, but it was a severe case of Avian Influenza. The Mexican veterinary health authority reported to OIE in June 21, 2012 the presence of exotic and high pathogenic virus type A/H7N3. In January 2013, two more cases of highly pathogenic avian influenza in non-vaccinated laying hen farms were reported in the state of Aguascalientes and after some weeks, some mortality reports emerged in poultry farms in the state of Guanajauto, located southeast of Jalisco (MÁRQUEZ, 2013). Moreover, Márquez (2013) showed that until the end of October, 2012, 22.3 million of birds died or were sacrificed, 160 millions of birds were vaccinated and more than 7000 jobs were lost with a total cost of US\$ 760 million.

Between the first outbreak in 2012 and the last in 2013, egg prices raised in average $\quad 73 \% \quad$ (SHERWELL \& SAWYER, 2013). The increase in prices found support in the drop of production and importation that were not able to supply the demand. Chicken meat prices had an average increase of $30 \%$, due to increased prices of fertile eggs and decrease in flock's numbers. High industrialized egg consumption, imported from USA, was expected. Avian Influenza outbreak was beneficial to poultry industry of USA, main chicken meat exporter to Mexico, with expectations of $15 \%$ high in chicken meat exportations whereas, for fresh and industrialized eggs, the potential of increase is from $500 \%$ and $200 \%$, respectively.

According to NI No. 59/2009, commercial avian facilities should contain wire mesh installation (not over 1-inch screen) in order to protect against the entrance of birds, domestic and wild animals as they are vehicles of diseases to production birds. Although the obligation of wire mesh use in laying commercial sheds was excluded in classic or modified type California systems (BRASIL, 2012).

Viana (2010) concluded that the best technical efficiency for biosecurity in avian shed was the use of wire mesh ( $\leq$ 0.8 inch or $19.11 \mathrm{~mm}$ screen), as the free-range birds could not overpass this mesh in the assays. The author considers the wire mesh (1 inch or 25.4 $\mathrm{mm}$ screen), proposed in the NI No. 59 (BRASIL, 2009), is inefficient to protect against free range birds and suggested the return of wire mesh $(\leq 0.8$ inch or $20 \mathrm{~mm}$ screen), as proposed by NI No. 56 (BRASIL, 2007).

Scenery IV presented the result considering wire mesh installation and salmonella sp. infection diagnosis, as according to NI No. 36, commercial classic or modified type California laying hen sheds (BRASIL, 2012) are considered the most susceptible to pathogenic agent introduction and should adopt additional measures to alleviate the risk of introduction and dissemination of diseases. It should also be submitted to a different risk management program that defines epidemiologic vigilance procedures to control different salmonella serotypes. As the egg is often associated by consumers to salmonella contamination and its better diagnosis and control can result in best quality eggs promoting a safer feeding with benefits to the population and obviously to poultry sector.

The costs for salmonella sp. exam diagnosis for the establishments of high susceptibility represented $17.13 \%$ in scenery III, where it is excluded wire mesh installation, and represented 
$14.54 \%$ in scenery IV. It was believed that the costs with salmonella sp. diagnosis exams would be lower than the implementation of other measures, such as wire mesh installation which represented $17.79 \%$ of biosecurity cost in scenery II and $15.19 \%$ in scenery IV, including that the costs of positive result for salmonella $\mathrm{sp}$. were not accounted. For this reason, the costs can be even lower $(0.63$ p.p). The production cost showed in scenery III in which the wire mesh installation is substituted by salmonella sp. exam, apparently represents lower cost for the producer. However, in this study the costs regarding the actions adopted on the establishments that had positive results for salmonella sp., such as costs with complementary exams, bird's treatment, destiny of egg production from positive birds, as well as birds culled from the flock. All these factors could be further studied.

The adoption of biosecurity measures to isolate the virus in the Mexican outbreak make the production costlier with an average increase of $10 \%$ in the prices of birds and fertile eggs (SHERWELL \& SAWYER, 2013). The same authors affirm that egg and meat consumption should increase but in a lower rhythm. They also consider that Mexico would leave the position of egg exporter to become an egg importer, as this country is the highest egg consumer in the world, even after decrease of $7.1 \%$ in consumption. For Márquez (2013), the most traumatic and painful experiences leave enriched knowledge that are hard to forget. For this reason, affirm the importance of other countries to learn with the Mexican experience, as the costs with biosecurity measures adoption are not an expense but an investment with return.

Researches that comprehend the analysis of egg production costs are scarce in literature, such as researches that evaluate social and economic impacts in this activity. In this way, due to the importance of poultry production to São Paulo state and to the country, studies that evaluate these impacts are essential for the introduction of new public policies. For example, it was believed that the adoption of biosecurity measures indicated by the Ministry of Agriculture, Livestock and Supply had some socioeconomic impact on commercial eggs production, eventually leading a producer to give up the activity. Besides the adequacies of documental and physical structure, it should also promote a shift of behavior in front of new demands, as for example, the implementation of Good Manufacturing Practices of production.

Despite the necessity for human resources application, this study suggests that the adjustments to biosecurity measures required by Normative instructions and, simulated for different sceneries, have relative low costs compared with the possible risks of diseases and the economic damages that these illnesses can cause. In this way, the adjustments are possible to be adopted, not justifying the abandonment of the activity.

The issue of cost is not the only problem for the correct establishment of the measures regulated by Normative Instructions. There are other complicating factors such as access to information, lack of management culture, lack of policies for agriculture credit and the successive alteration in the legislation that can lead the avian sanitation program to lose its credibility in front of the society and the producers that show resistance to changes in animal science paradigms. 


\section{REFERENCES}

BRASIL. Ministério da Agricultura Pecuária e Abastecimento (MAPA). 1994. Portaria Ministerial No. 193 de setembro, 1994. Institui o Programa Nacional de Sanidade Avícola no âmbito da SDA e cria o Comitê Consultivo do Programa de Sanidade Avícola. Diário Oficial [da] União, Brasília, DF, 22 Setembro, 1994. Seção 1:14309.

BRASIL. Ministério da Agricultura Pecuária e Abastecimento (MAPA). 2007. Instrução Normativa - MAPA No. 56 de 04 de dezembro, 2007. Estabelece os Procedimentos para Registro, Fiscalização e Controle de Estabelecimentos Avícolas de Reprodução e Comerciais. Diário Oficial [da] União, Brasília, DF, 06 Dezembro, 2007. Seção 1:11.

BRASIL. Ministério da Agricultura Pecuária e Abastecimento (MAPA). 2009. Instrução Normativa No. 59 de 02 de dezembro, 2009. Altera a Instrução Normativa MAPA No. 56, de 04 de dezembro, 2009. Diário Oficial [da] União, Brasília, DF, 04 Dezembro, 2009. Seção 1:4.

BRASIL. Ministério da Agricultura Pecuária e Abastecimento (MAPA). 2012. Instrução Normativa No. 36, de 06 de dezembro, 2012. Altera, renumera, acrescenta e revoga, anexos, artigos, parágrafos e incisos da Instrução Normativa No. 56. Diário Oficial [da] União, Brasília, DF, 07 Dezembro, 2012. Seção 1:25.

BRASIL. Ministério da Agricultura Pecuária e Abastecimento (MAPA). 2013. Instrução Normativa No. 50, de 24 de setembro de 2013. Alterar a lista de doenças passíveis da aplicação de medidas de defesa sanitária animal, previstas no art. 61 do Regulamento do Serviço de Defesa Sanitária Animal, publicado pelo Decreto n 24.548, de 03 de Julho, 1934. Diário Oficial [da] União, Brasília, DF, 25 Setembro, 2013. Seção 1:47.

DUMAS, M.D.; POLSON, S.W.; RITTER, D.; RAVEL, J. GELB JR., J.; MORGAN, R.; WOMMACK, K.E. Impacts of poultry house environment on poultry litter bacterial community composition. Plos One, v.6, n.9, p.1-12, 2011.

MÁRQUEZ, M. A. Um foco de Influenza Aviária tipo A/H7N3 de Alta Patogenicidade e exótica em Jalisco, 2012, e Guanajuato-Puebla, 2013, México. In: CONGRESSO BRASILEIRO DE AVICULTURA, 23., 2013, São Paulo. Anais... São Paulo, 2013.

MICROSOFT. Microsoft Office Excel $^{\circledR}$. California: Microsoft Corporation. 2007.

ORGANIZAÇÃO MUNDIAL DE SAÚDE ANIMAL - OIE. Listed diseases, infections and infestations in force in 2014. Paris, France, 2014.

RAINERI, C.; STIVARI, T.S.S.; GAMEIRO, A.H. Development of a cost calculation model and cost index for sheep production. Revista Brasileira de Zootecnia, v.44, p.443-455, 2015.

SÃO PAULO (Estado). 1998. Decreto Estadual No. 43.424, de 01 de setembro, 1998. Altera a subordinação e o nível do Departamento de Defesa Agropecuária da Coordenadoria de Assistência Técnica Integral (CATI) na Secretaria de Agricultura e Abastecimento. Diário Oficial do Estado, 02 Agosto, p.5, 1998. 
SEAGRI. Secretaria de Agricultura e Desenvolvimento Rural do Distrito Federal. Dois anos para mudar. 2010. Disponível em:

$<$ http://www.seapa.df.gov.br /003/00301009.asp?ttCD_CHAVE=947

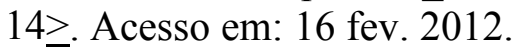

SESTI, L.A.C.; MACARI, M.; MENDES, A.A. Biosseguridade em granjas de reprodutoras. In: MACARI M, MENDES AA. Manejo de matrizes de cortes. Campinas: FACTA, 2005. p.243-317.

SHERWELL, P.; SAWYER, W.

Recovering from a bad case of the flu. Rabobank Industry Note, n.414, p.7, 2013.

VEIGA, L.; GONDIM, S. M. G. A utilização de métodos qualitativos na ciência política e no marketing político. Opinião Pública, v.2, n.1, p.1-15, 2001.

VIANA, G.R. Eficiência de telas de arame na segregação de aves de vida livre para a biossegurança de aviários comerciais. 2010. 62p. Dissertação (Mestrado) - Universidade Federal de Minas Gerais, Belo Horizonte.

Data de recebimento: $24 / 10 / 2016$

Data de aprovação: 29/03/2017 